\title{
Description of the Training Activities for Transmigrant Candidates
}

\author{
Malta \\ Faculty of Science and Technology \\ Universitas Terbuka, Tangerang Selatan \\ Indonesia \\ Sumardjo \\ Anna Fatchiya \\ Djoko Susanto \\ Faculty of Human Ecology \\ IPB University, Bogor \\ Indonesia
}

\begin{abstract}
In an effort to improve the competencies of prospective migrants to become competitive transmigrant candidates, the training for prospective migrants, if it is carried out with careful planning and shows encouraging results, will really help the training participants. The prospective transmigrants who have joined the training before departure will get a lot of benefits to continue their lives in a new place successfully. The study was conducted from May 2016 to January 2017. The population was 3,537 transmigrant households. The sample size of this study was determined using the Slovin formula. The number of the samples was 359 respondents. The sampling was done using stratified random sampling. The research data consisted of primary data and secondary data. The primary data were obtained through structured interviews, in-depth interviews, and observations in the field. The influence between variables was tested using SEM (Structural Equation Modeling). The study results showed that the description of training activities for prospective transmigrants in the area of origin includes 2-4 types of training, low suitability of training material, low method suitability, and moderate instructor ability.
\end{abstract}

Keywords: training, transmigrant candidates

\section{Introduction}

In an effort to evenly distribute the population and to encourage regional growth, the Indonesian government has been implementing a program of population movement from densely populated areas to sparsely populated ones. The program is called Transmigration and the relocated population is called Transmigrants.

Transmigration as a model of community development has 3 (three) main targets: (1) to increase the ability and productivity of transmigration communities and the communities around the transmigration settlements, (2) to build the independence of transmigrants and the communities around transmigration settlements, and (3) to realize the integration in transmigration settlements so that the economic and social culture can grow and develop in a sustainable manner. The essence of the targets is expected to be able to build communities through efforts to empower and develop the potential of regional resources.

Prospective transmigrants to be sent from theirplace of origin generally have the average level of education, experience, and skills which are relatively low. In addition, they also have inadequate knowledge of the conditions of the placement area. Therefore, training for prospective transmigrants is a fundamental requirement that is highly prioritized for the success of the transmigration program. In an effort to improve the competencies of prospective migrants to become competitive transmigrant candidates, the training for prospective migrants, if it is carried out with careful planning and shows encouraging results, will really help the training participants. The prospective transmigrants who have joined the training before departure will get a lot of benefits to continue their lives in a new place successfully.

The description of the training activities for prospective migrants is very important to be studied, the result of which can then be used as a basis in developing training activities for prospective transmigrants. The aim of this study is to analyze the description of training activities for prospective transmigrants in the area of their origin. 


\section{Results and Discussion}

The training activities for prospective transmigrants in the area of origin can be described as follows: the training consisted of 2-4 types, the suitability of training material was low, the suitability of methods was low, and the ability of instructors was moderate (Table 1). This condition also illustrates the quality of debriefing for prospective transmigrants before being sent to the transmigration location. Here is a more detailed explanation.

\section{Number of Training Types}

Before occupying the transmigration location, prospective transmigrants were given training in the area of origin. There were variations in the amount of training that prospective migrants received. The training, which was conducted in the area of origin, aimed to equip transmigrants with certain skills and knowledge as well as to galvanize the mentality of prospective transmigrants to be ready to face all challenges after getting to the transmigration area. The training was conducted by the n Office which handles the affairs of transmigration in the area of origin. The duration of training ranged from 5-7 days. The types of training received were in the form of: (1) general basic training, (2) entrepreneurship training, (3) an explanation of the rules or policies for implementing transmigration, and (4) mental religious guidance; each type of training consisted of several topics.

Table 1. Distribution of respondents based on training of prospective transmigrants

\begin{tabular}{|c|c|c|c|c|}
\hline \multirow{3}{*}{$\begin{array}{l}\text { Sub-Variable Training for } \\
\text { Prospective Transmigrants }\end{array}$} & \multirow{3}{*}{ Category } & \multicolumn{2}{|l|}{ Regency } & \multirow[b]{2}{*}{$\begin{array}{l}\text { Total } \\
(\mathrm{n}=359)\end{array}$} \\
\hline & & $\begin{array}{l}\text { Banyuasin } \\
(\mathrm{n}=284)\end{array}$ & $\begin{array}{l}\text { Ogan Ilir } \\
(\mathrm{n}=75)\end{array}$ & \\
\hline & & $\%$ & $\%$ & $\%$ \\
\hline & 2 types & 9.2 & 18.7 & 11.1 \\
\hline Number of training types $* *$ & 3 types & 16.2 & 29.3 & 19.0 \\
\hline \multirow[t]{3}{*}{ Average score: 79.4} & 4 types & 74.6 & 52.0 & 69.9 \\
\hline & Total & 100.0 & 100.0 & 100.0 \\
\hline & low & 70.8 & 80.0 & 72.7 \\
\hline Suitability of training material & medium & 15.8 & 8.0 & 14.2 \\
\hline \multirow[t]{3}{*}{ Average score: 38.8} & Suitable & 13.4 & 12.0 & 13.1 \\
\hline & Total & 100.0 & 100.0 & 100.0 \\
\hline & low & 52.5 & 86.7 & 59.6 \\
\hline Suitability of training methods $* *$ & medium & 43.3 & 8.0 & 35.9 \\
\hline \multirow[t]{3}{*}{ Average score: 44.8} & Suitable & 4.2 & 5.3 & 4.5 \\
\hline & Total & 100.0 & 100.0 & 100.0 \\
\hline & low & 37.3 & 25.3 & 34.8 \\
\hline Instructor ability & medium & 19.7 & 62.7 & 28.7 \\
\hline \multirow[t]{2}{*}{ Average score: 62.4} & high & 43.0 & 12.0 & 36.5 \\
\hline & Total & 100.0 & 100.0 & 100.0 \\
\hline
\end{tabular}

Note: $* *$ the difference is very significant at $\alpha=0.01$

The average score: Low $=0-50$, Medium $=51-75$, High $=76-100$

Training and development are steps in an effort to ensure that someone has the knowledge and skills needed to carry out their work (Departemen Pertanian 2006). Through training before leaving for the transmigration site, the transmigrants have an overview of the conditions of the site to go to, in addition to knowledge and technical skills, so the training is expected to strengthen the readiness of the prospective transmigrants to start a new life at the transmigration site.

Training is an effort to improve one's skills in carrying out a particular job, and the training itself must be able to cause changes in the trainee. In this case, through training, transmigrants can develop their empowerment, which can make transmigrants open to new experiences and ideas, oriented to the present and the future, so that they are able to independently manage and develop their farming well.

\section{Suitability of Training Materials}

The suitability of the material for prospective transmigrants in training activities in the area of origin was relatively low (Table 1). This means that the training material for prospective transmigrants was not yet fully in accordance with the needs and problems of transmigrants in transmigration locations. The suitability indicators of training material are presented in Table 2. 
Table 2. Percentage of respondents based on perceptions about the suitability of the training material for prospective transmigrants.

\begin{tabular}{|c|c|c|c|c|c|c|}
\hline \multirow{3}{*}{ Indicator } & \multicolumn{2}{|c|}{$\begin{array}{l}\text { Banyuasin } \\
(\mathrm{n}=284)\end{array}$} & \multicolumn{2}{|c|}{$\begin{array}{l}\text { Ogan } \\
(\mathrm{n}=75)\end{array}$} & \multicolumn{2}{|c|}{ Total $(n=359)$} \\
\hline & Less & Yes & Less & Yes & Less & Yes \\
\hline & $(\%)$ & $(\%)$ & $(\%)$ & $(\%)$ & $(\%)$ & $(\%)$ \\
\hline $\begin{array}{l}\text { Conformity of material with land } \\
\text { conditions }\end{array}$ & 59.9 & 40.1 & 60.0 & 40.0 & 59.9 & 40.1 \\
\hline Ease of application & 95.8 & 4.2 & 94.7 & 5.3 & 95.5 & 4.5 \\
\hline $\begin{array}{l}\text { Material conformity with the problem of } \\
\text { transmigrants }\end{array}$ & 86.6 & 13.4 & 88.0 & 12.0 & 86.9 & 13.1 \\
\hline
\end{tabular}

Prospective transmigrants originating from local residents (local transmigrants) received training materials that were suitable to the land conditions at the transmigration site; however prospective transmigrants from Java Island receivedthe material substance that was different from the real conditions at the transmigration site. The farm land in transmigration site was tidal and swampy with high soil acidity (very low soil $\mathrm{pH}$ ), while the material provided during the training before leaving was about farming on dry land and irrigation.

The material substance is an important aspect in a training. The training material must be in accordance with the learning objectives, the needs of transmigrants, and the situation on the transmigration site. The training material must also be appropriate for the level of education of transmigrants to make it easier to understand. According to Wahyudin (2012) and Rubiyanti et al. (2012), training materials must be in accordance with the learning needs of learners, so that they are attractive to trainees and stimulated to practice them. Yulianto (2008) adds that the training will be more efficient and effective if participants get training materials that are in accordance with their potential and needs.

Most of the training materials ( 75 percent) for prospective transmigrants were in the form of materials on agriculture, including making organic fertilizer, learning to transplant, operating tractors, food crops and horticulture, not to mention learning to do artificial insemination in cows, and poultry farming; in addition, it also provided welding training. Participants were also equipped with knowledge about the conditions or general description of the destination along with the culture and traditions of the local community (for prospective migrants from outside the province), rights and obligations as transmigrants, national insights, and material for increasing motivation, as well as mental attitude to advance.

The management concept was also given to prospective transmigrants in the form of entrepreneurship and group dynamics. The participants were also equipped with agricultural product processing skills, namely making tofu, soybean tempeh, banana dodol, virgine coconut oil (VCO), sweet potato flour, and handicrafts from banana trees. The transmigrants' wives were also trained so that they have the skills to make soy sauce, soy milk, egg noodles, fish floss, instant ginger, vegetable chips, corn chips, bakpia from sweet potatoes, and mochi cakes.

The training materials related to social and managerial knowledge would benefit transmigrants; however, training materials related to processing of agricultural products and entrepreneurship could not be fully implemented. The transmigrants stated that the duration of the training related to skills was too short with many topics, so that the transmigrants were not yet skilled in making the products taught, in addition to reasons for limited business capital and predictions of difficulty in marketing the product to be produced.

\section{Suitability of Training Methods}

The suitability of the training methods for prospective migrants in training activities in the area of origin was in the low category (Table 1). The low suitability of the method of delivering this training material was becausein the training carried out generally the trainer used the lecture method, not practical methods, let alone internships. Several topics were carried out demonstrations and practices, but tools for practice were limited, so that not all participants had the opportunity to practice the material / subject matter provided (Table 3). Time constraints also contributing to thisasa large number of topics in training with a limited number of training days. This condition had made the training less effective.

The method used in delivering training materials will affect the level of understanding of the participants to the material presented. The instructor in choosing a training method should depend on the objectives to be achieved and the circumstances of the trainees. 
Table 3. Percentage of respondents based on perceptions about the suitability of training methods for prospective transmigrants

\begin{tabular}{llllllll}
\hline \multirow{2}{*}{ Indicator } & \multicolumn{2}{l}{$\begin{array}{l}\text { Banyuasin } \\
(\mathrm{n}=284)\end{array}$} & \multicolumn{2}{c}{ Ogan Ilir $(\mathrm{n}=75)$} & \multicolumn{2}{c}{ Total (n=359) } \\
\cline { 2 - 7 } & & Less & Yes & Less & Yes & Less & Yes \\
\cline { 2 - 7 } & $(\%)$ & $(\%)$ & $(\%)$ & $(\%)$ & $(\%)$ & $(\%)$ \\
\hline $\begin{array}{l}\text { The accuracy of the example } \\
\text { demonstrated with the material discussed }\end{array}$ & 52.5 & 47.5 & 68.0 & 32.0 & 55.7 & 44.3 \\
$\begin{array}{l}\text { The accuracy of the example given with } \\
\text { the problem at hand }\end{array}$ & 86.6 & 13.4 & 94.6 & 5.4 & 88.3 & 11.7 \\
Participatory involvement of participants & 85.9 & 14.1 & 94.7 & 5.3 & 87.7 & 12.3 \\
\hline
\end{tabular}

Methods that are less attractive and less appropriate to the conditions and needs of trainees can be classified as "bank style" learning methods. As explained by Freire (1984), with the "bank style" learning method, instructors do not see the trainees as dynamic and creative individuals but are seen as individuals or containers to accommodate a number of formulations or propositions. The instructor in the learning process does not provide understanding but transfers a number of propositions or formulations to trainees who will be issued in the same form if needed. In this style of training, the trainee becomes a person who memorizes teaching materials that are poor in creativeness to free themselves from powerlessness.

Freire (1984) offers a "problem-facing" method as an alternative method in training that comes up based on the conception of humans. As humans, trainees have the potential to be creative; therefore, trainees are not seen and placed as objects that must be taught and accepted, otherwise the instructor does not function as a teacher. In fact, the instructor and trainee are both learning from the problem at hand. Furthermore, the instructor and trainee are both subject in problem solving. The instructor serves as a facilitator who facilitates dialogic communication and becomes a friend in solving problems, while the trainees take positions as active participants in dialogic communication during the training.

\section{Instructor Ability}

The ability of instructors in training activities for prospective transmigrants in the area of origin was classified as moderate (Table 1). That is, the ability of instructors was not optimal in communicating and motivating in training activities. The transmigrants mentioned that the instructors were quite capable in providing training materials, but the instructors did not know for certain the things that were actually needed by the transmigrants in farming activities to be carried out at the transmigration site (Table 4).

Table 4. Percentage of respondents based on perceptions about the instructors'ability of prospective transmigrant training

\begin{tabular}{llllllll}
\hline \multirow{2}{*}{ Indicator } & \multicolumn{2}{l}{$\begin{array}{l}\text { Banyuasin } \\
(\mathrm{n}=284)\end{array}$} & \multicolumn{2}{l}{ Ogan Ilir $(\mathrm{n}=75)$} & \multicolumn{2}{l}{ Total $(\mathrm{n}=359)$} \\
\cline { 2 - 8 } & $\begin{array}{l}\text { Less } \\
\text { able }\end{array}$ & able & $\begin{array}{l}\text { Less } \\
\text { able }\end{array}$ & able & $\begin{array}{l}\text { Less } \\
\text { able }\end{array}$ & able \\
\cline { 2 - 8 } & $(\%)$ & $(\%)$ & $(\%)$ & $(\%)$ & $(\%)$ & $(\%)$ \\
\hline Ability to convey meterial & 27.5 & 72.5 & 16.0 & 84.0 & 25.1 & 74.9 \\
Abilty to motivate & 39.4 & 60.6 & 33.3 & 66.7 & 38.1 & 61.9 \\
Abilty to analyze a problem & 54.9 & 45.1 & 78.7 & 21.3 & 59.9 & 40.1 \\
\hline
\end{tabular}

The instructors in the training activities for prospective transmigrants came from the Transmigration Training Center where the transmigrants came from. The organizers also involved practitioners as instructors, but there was a lack of information to the instructors regarding the real conditions at the transmigration site that the transmigrants would be visiting.

One component of training activities that has an important role in the success of training is the presence of instructors. The instructor's ability to properly communicate the material in training is very necessary so that participants can understand the material presented. 
According to Yulianto (2008), an instructor needs to master effective communication techniques, motivating techniques, fostering a sense of the usefulness of practice, a sense of need to learn, and a sense of fun learning to trainees. Warisdiono et al. (2013) states that instructors must be able to create a conducive and effective learning environment and be able to manage classrooms and bring training participants to achieve optimal learning outcomes. The instructor ability of is very important for the training provider to ensure the quality of training implementation in accordance with the expectations and needs of participants.

\section{Conclusion}

The description of training activities for prospective transmigrants in the area of origin includes 2-4 types of training, low suitability of training material, low method suitability, and moderate instructor ability.

\section{References}

Departemen Pertanian. 2006. Laporan Studi Dampak Pelatihan Pertanian. Jakarta (ID): Deptan.

Freire P. 1984.Pendidikan, Pembebasan, dan Perubahan Sosial. Joebhar M, penerjemah. Jakarta (ID): PT. Sangkala Pulsar. Terjemahandari: Pedagogy of the Oppressed.

Rubiyanti Y, Novianti LE, Supyandi D. 2012. PelatihanmotivasiberprestasidanorientasimasadepanremajaJatinangor. Sosiohumaniora - JurnalImu-ilmu Sosialdan Humaniora. 14(1):1-11.

Wahyudin

2012.Pelatihankewirausahaanberlatarekokulturaluntukpemberdayaanmasyarakatmiskinpedesaan.MIMBAR

$\mathrm{U}$. Jurnal Sosialdan Pembangunan. 28(1):55-64.

Warisdiono E, Sarma M, Gani DS, Susanto

D.2013.Kompetensifasilitatorpelatihanpusatpengembangandanpemberdayaanpendidikdantenagakependidikanp ertanian.JurnalPenyuluhan. 9(2):109-119.

Yulianto G. 2008. Evaluasi program pelatihantenagabantupenyuluhpertanian. JurnalM'Power. 8(8):74-91. 